\title{
Primary Male Breast Cancer: Analysis of Eight Cases and Review of Literature

\author{
JU AHMED ${ }^{\mathrm{a}}$, MM HUSSAIN ${ }^{\mathrm{b}}$
}

\begin{abstract}
Summary:
This is a hospital based retrospective study with 8 cases of newly diagnosed primary male breast cancer. Among 413 cases of breast cancer of both male and females, treated between 1988 to 2002 at Chittagong, eight were males. The incidence is $1.94 \%$. The mean age of diagnosis is 50.13 years, which is later than females. A breast mass was the earliest, most important symptom. The duration of symptoms before treatment ranged from few weeks to
\end{abstract}

\section{Introduction:}

Male breast cancer is comparatively rare, constituting $0.38 \%-1.5 \%$ of all male cancers, ${ }^{1}$ and $1 \%$ of all diagnosed breast carcinomas ${ }^{2}$. Unfortunately, male breast cancer is often diagnosed at a late stage because of the minimal awareness of presenting symptoms by the patients. Because of the late presentation, the overall prognosis is less favorable.

A review of 198 articles revealed that important risk factors in male breast cancer are advanced age, a positive family history, Jewish origin, black race, excess exposure to female hormones e.g. Kline-Felter's syndrome, environmental exposure like irradiation , alcohol, obesity, higher socioeconomic status \& childlessness ${ }^{3}$. Gynaecomastia remains a controversial factor. Advanced disease is characterized by pain, bloody discharge $\&$ skin ulceration. There is no definite diagnostic algorithm. Experience with male breast mammography is limited, FNAC tends to overestimate the rate of malignancy. The commonest histologic finding is infiltrating duct cell carcinoma ${ }^{3}$.

Factor influencing patients prognosis include clinical stage of disease, histological type of tumor, grade of malignancy, presence or absence of axillary lymph nodes metastasis and distant metastasis.

This paper describes the clinical \& pathological features of these eight cases and discusses the

a) Dr. Jashim Uddin Ahmed, FCPS, Associate Professor of Surgery, Chittagong Medical College, Chittagong

b) Prof. Md. Margub Hussain, FCPS, MHPEd, Professor of Surgery, Chittagong Medical College, Chittagong

Address of Correspondence: Dr. Jashim Uddin Ahmed, FCPS, Associate Professor of Surgery, Chittagong Medical College, Chittagong.

Received: 25 September, 2005

Accepted: 15 December, 2006 years .Male breast cancer is of the same common pathologic types as in females that is $75 \%$ patients had duct cell carcinoma. The rarity of the tumor hinders the study of its biological behavior and etiology, which in consequence, are still not well understood. As with the female breast cancer, surgical excision followed by adjuvant CT, RT, hormone therapy are the treatment modalities.

(J Bangladesh Coll Phys Surg 2007; 25 : 18-22)

correlation between clinico pathological features and prognosis in the light of a brief review of the relevant literatures.

\section{Methodology}

For this retrospective study, hospital records and operation registers were used. Case records were collected and preserved separately for all cases of males admitted and treated for breast cancer. Among 413 cases of carcinoma breast, treated between 1988 to 2002, eight (08 ) were males. These were all histopathologically confirmed before definitive treatment offered.

\section{Ethical Issues}

Ethical clearance was obtained from Chittagong Medical College Ethical Review Committee for the study . Informed consent was obtained from each patient regarding clinical photographs and for later use anonymously for publication and presentation.

\section{Results:}

Eight ( 8 ) cases of primary male breast cancer were treated among 413 cases of breast cancers. These eight cases were analysed . The incidence is $1.94 \%$, indicating the male to female ration of approximately 2 to 100 .

Table-I

\begin{tabular}{lcc}
\multicolumn{3}{c}{$\begin{array}{c}\text { Showing age distribution in eight cases } \\
\text { male breast cancer }\end{array}$} \\
Age in years & No of cases & $\%$ \\
\hline $21-30$ & 1 & $12.5 \%$ \\
$31-40$ & 1 & $12.5 \%$ \\
$41-50$ & 0 & 0 \\
$51-60$ & 6 & $75 \%$ \\
\hline
\end{tabular}


The youngest patient in the series was 26 years of age and oldest was 60 years, with a mean age of 50.13 years. The highest incidence was in the $6^{\text {th }}$ decade of life. All the cases had unilateral breast cancer, 6 had right sided \& 2 had left sided breast cancer. Age distribution and histological findings are shown in table I and table II.

\section{Table-II}

\begin{tabular}{|c|c|c|}
\hline \multicolumn{3}{|c|}{$\begin{array}{l}\text { Histological findings in eight cases of } \\
\text { male breast cancer }\end{array}$} \\
\hline Histological type & No of cases & $\%$ \\
\hline Duct cel & 6 & $75 \%$ \\
\hline Sq cell carcinoma & 1 & $12.5 \%$ \\
\hline FNAC - malign. cells & 1 & $12.5 \%$ \\
\hline
\end{tabular}

All patients were Muslims, having a variety occupations. None of patients showed any apparent relationship with religion \& occupations. Attempts were made to find out etiological factors in male breast cancers, only one patient had preexisting gynaecomastia, none other patients had any known predisposing factors. All cases were staged according to the TNM classification and Manchester staging. Majority of primary breast cancer were diagnosed in stage III (62.5\%), no case was found in stage I.

Simple mastectomy was done in six cases (75\%), one was inoperable due to chest wall fixation, one patient refused operation.

Only few patients could be followed up to 6 months to 8 years, one patient returned with spinal metastasis with paraplegia, bed sores after 8 years.

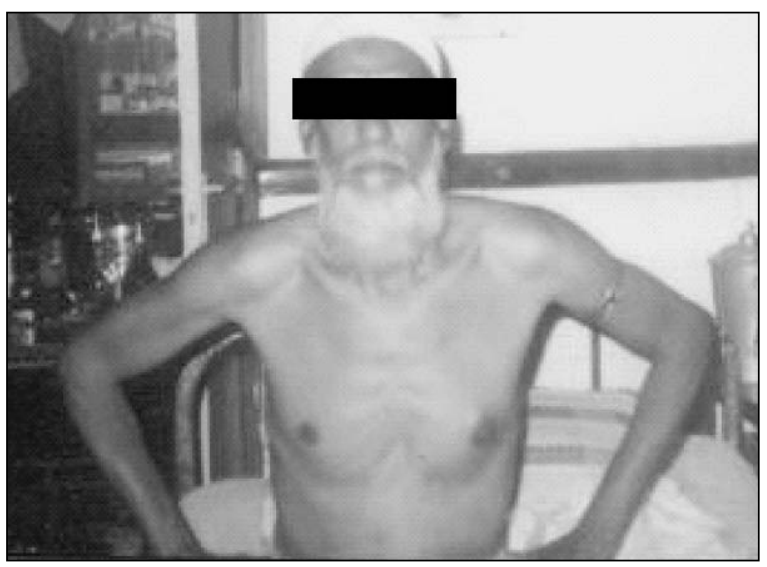

Fig-1: Stage II, Duct cell Carcinoma, in a man of 60 Years

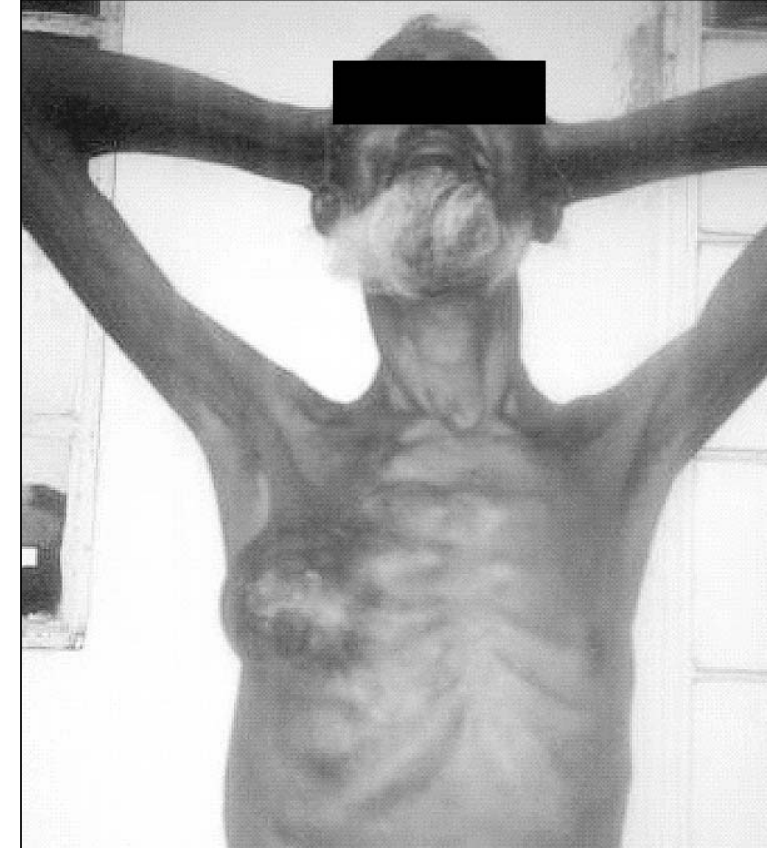

Fig-2: Stage III, Squamous cell Carcinoma, In a man of 60 Years

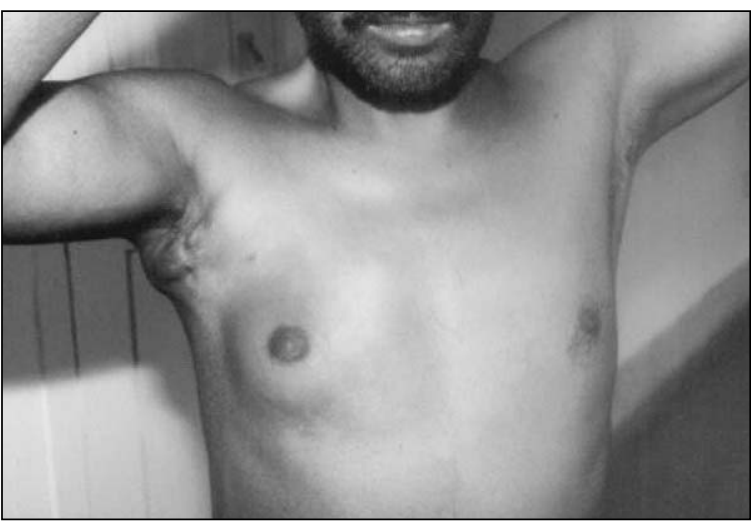

Fig-3: Stage III, Sarcomatous Lesion, in a man of 35 Years

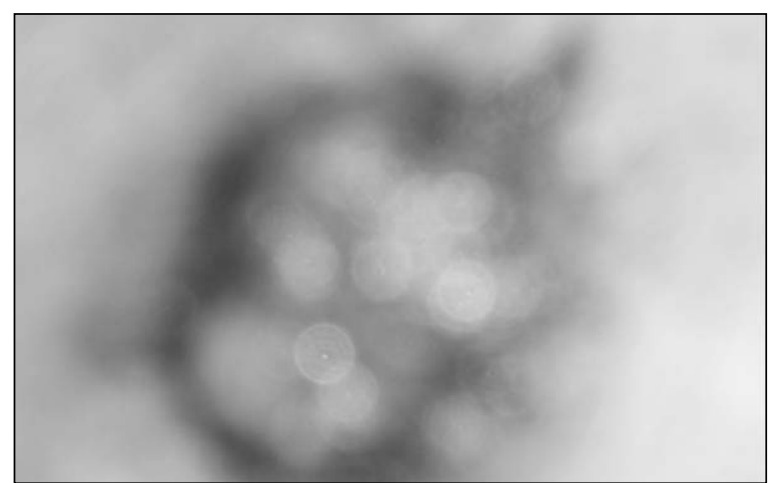

Fig-4: Stage III, Duct cell Carcinoma In a Man of 50 Years 
Results:

Summary of Clinicopathologic Data of 8 Cases

\begin{tabular}{|c|c|c|c|c|c|c|c|c|c|}
\hline & Age & Initial symptoms & $\begin{array}{c}\text { Duration } \\
\text { before RX. } \\
\text { (Month) }\end{array}$ & $\begin{array}{l}\text { Clinical } \\
\text { stage }\end{array}$ & $\begin{array}{l}\text { Axillary } \\
\text { LNs }\end{array}$ & Metastasis & $\begin{array}{l}\text { Histologic } \\
\text { type }\end{array}$ & Operation & Follow-up \\
\hline $\begin{array}{l}\text { Case }-1 \\
\text { (Fig: 1) }\end{array}$ & $60 \mathrm{Y}$ & $\begin{array}{l}\text { Lt. Breast lump in } \\
\text { upper outer } \\
\text { quadrant } 5 \mathrm{X} 5 \mathrm{~cm}\end{array}$ & 12 & $\begin{array}{l}\text { Stage II } \\
\mathrm{T} 2 \mathrm{~N}_{1}, \mathrm{Mo}\end{array}$ & $\begin{array}{l}\text { Single } \\
\text { Mobile }\end{array}$ & No & Duct cell CA & $\begin{array}{l}\text { Simple } \\
\text { Mastectomy } \\
\text { with axillary } \\
\text { Dissection }\end{array}$ & $\begin{array}{l}8 \text { years after } \\
\text { operation } \\
\text { spinal } \\
\text { Metastasis, } \\
\text { paraplegia }\end{array}$ \\
\hline $\begin{array}{l}\text { Case }-2 \\
\text { (Fig: 2) }\end{array}$ & $60 \mathrm{Y}$ & $\begin{array}{l}\text { Rt. Breast lump in } \\
\text { central part, Fixed } \\
\text { with chest wall } \\
7 \mathrm{X} 5 \mathrm{~cm} \text {. }\end{array}$ & 6 & $\begin{array}{l}\text { Stage III } \\
\text { T4 No Mo }\end{array}$ & No & No & Sq cell -CA & $\begin{array}{l}\text { Incisional } \\
\text { biopsy only } \\
\text { (Inoperable) }\end{array}$ & \\
\hline Case-3 & $55 \mathrm{Y}$ & $\begin{array}{l}\text { Lt. Breast lump in } \\
\text { lower outer } \\
\text { quadrant } 7 \mathrm{X} 6 \mathrm{~cm} \text {. }\end{array}$ & 3 & $\begin{array}{l}\text { Stage III } \\
\text { T3 N2 Mo }\end{array}$ & $\begin{array}{l}\text { Multiple } \\
\text { hard } \\
\text { fixed }\end{array}$ & No & Duct cell CA & $\begin{array}{l}\text { Simple } \\
\text { Mastectomy \& } \\
\text { axillary } \\
\text { Dissection }\end{array}$ & $\begin{array}{l}6 \text { month after } \\
\text { operation } \\
\text { symptom less }\end{array}$ \\
\hline Case -4 & $26 \mathrm{Y}$ & $\begin{array}{l}\text { Rt. Breast lump } \\
\text { Central part nipple } \\
\text { areola fixed 5X5 } \\
\mathrm{cm} .\end{array}$ & 36 & $\begin{array}{l}\text { Stage II } \\
\text { T2 No Mo }\end{array}$ & No & No & Duct cell CA & $\begin{array}{l}\text { Simple } \\
\text { Mastectomy }\end{array}$ & \\
\hline $\begin{array}{l}\text { Case }-5 \\
\text { (Fig: 3) }\end{array}$ & $35 \mathrm{Y}$ & $\begin{array}{l}\text { Rt. Breast lump } \\
\text { upper outer } \\
\text { quadrant } 5 \mathrm{X} 4 \mathrm{~cm}\end{array}$ & 40 & $\begin{array}{l}\text { Stage III } \\
\text { T2 N2 Mo }\end{array}$ & $\begin{array}{l}\text { Multiple } \\
\text { hard } \\
\text { fixed }\end{array}$ & No & $\begin{array}{l}\text { Sarcomatous } \\
\text { lesion }\end{array}$ & $\begin{array}{l}\text { Simple } \\
\text { Mastectomy \& } \\
\text { axillary } \\
\text { Dissection }\end{array}$ & \\
\hline Case- 6 & $60 \mathrm{Y}$ & $\begin{array}{l}\text { Rt. Breast lump } \\
\text { upper part 7X5 cm. }\end{array}$ & 6 & $\begin{array}{l}\text { Stage III } \\
\text { T3 No Mo }\end{array}$ & No & No & Duct cell CA & $\begin{array}{l}\text { Simple } \\
\text { Mastectomy }\end{array}$ & $\begin{array}{l}6 \text { month after } \\
\text { operation } \\
\text { found ok }\end{array}$ \\
\hline $\begin{array}{l}\text { Case }-7 \\
\text { (Fig: } 4 \text { ) }\end{array}$ & $50 \mathrm{Y}$ & $\begin{array}{l}\text { Rt. Breast lump } \\
\text { lower outer } \\
\text { quadrant } 8 \times 7 \mathrm{~cm} \text {. }\end{array}$ & 6 & $\begin{array}{l}\text { Stage III } \\
\text { T3 No Mo }\end{array}$ & No & No & $\begin{array}{l}\text { Infiltration } \\
\text { Duct cell CA }\end{array}$ & $\begin{array}{l}\text { Simple } \\
\text { Mastectomy }\end{array}$ & $\begin{array}{l}2 \text { year after } \\
\text { operation } \\
\text { found ok }\end{array}$ \\
\hline Case- 8 & $55 \mathrm{Y}$ & $\begin{array}{l}\text { Rt. Breast lump } \\
\text { subareolar } 4 \text { X2.5 } \\
\mathrm{cm} \text {. }\end{array}$ & 12 & $\begin{array}{l}\text { Stage II } \\
\text { T2 No Mo }\end{array}$ & No & No & $\begin{array}{l}\text { FNAC- } \\
\text { Malig. Cells } \\
\text { and atypical } \\
\text { mitosis seen }\end{array}$ & $\begin{array}{l}\text { Refused } \\
\text { Operation }\end{array}$ & $\begin{array}{l}\text { after } 1 \text { year } \\
\text { axillary LN } \\
\text { were palpable }\end{array}$ \\
\hline
\end{tabular}

\section{Discussion:}

Primary carcinoma of the male breast is uncommon when compared to female mammary cancer ${ }^{4}$. The first reported case of primary carcinoma of the male breast appeared in the medical publications of Franciscus Arcaneus (1493-1573) ${ }^{5}$. Since that time various reports concur that carcinoma of male breast is uncommon; therefore has not been studied as extensively as carcinoma of female breast.

In the present study, $1.94 \%$ of breast cancer occurred in males, indicating a male to female ration of approximately 2 to100. This figure is slightly lower than $2.5 \%$ incidence of male breast cancer reported in the series of Treves \& Holleb ${ }^{6}$, Moss ${ }^{7}$, Sachs ${ }^{8}$, Payson \& Rosh ${ }^{9}$, Holleb et $\mathrm{al}^{10}$. Review of the literature compiles an average incidence of cancer of the breast at $7 \%$ of all cancers of males. Pack and Le Fevre ${ }^{11}$ found that male breast cancer comprised $0.41 \%$ of all male cancers. Williams ${ }^{12}$ in 1889 analysed 2444 breast tumours in four London hospitals. There were a male to female ratio of approximately $\mathrm{l}$ to 100 in his analysis at these hospitals.

Wain Wright ${ }^{13}$ found an average age of 54.2 years among 401 cases. Average ages in other representative series include: Sachs 857 , Huggins ${ }^{14} 64$, Bryan ${ }^{15}$ 60, Somerville 55.1, Neal ${ }^{16} 57.7$, Charache ${ }^{17} 62$ and Gilbert ${ }^{18} 54.4$. The average age appears to be about 10 years older than for that of female breast cancer ${ }^{19-35}$.

In the present series, the 51-60 years age population was at highest risk, with a mean age of 50.13 years. The opinion of nearly all observers, including the authors of the present series are similar that breast cancer develops at a later age in male than females. Bryan ${ }^{15}$ in 1914 reported a case of breast cancer in a 12 years old male and Charache ${ }^{17}$ a case in a male at ninety years of age. 
Gilbert ${ }^{18}$ in an early series from Memorial Hospital noted 9 patients with gynaecomastia among 47 Male breast cancer patients and claimed that patients with gynaecomastia are liable to develop cancer. Geschickter $^{23}$ also assumed that gynaecomastia predisposes to breast cancer. Heller KS et al also claimed that $40 \%$ of patients with male breast cancer will have microscopic gynaecomastia . Similar observation were also made by others. ${ }^{34-36}$ In the present study, author found only one patient of male breast cancer had preexisting gynaecomastia (.08\%)No other aetiological factors could be sought among the patients. XU RN 39 treated 43 cases of male breast cancer in the past 3 decades. $67.7 \%$ of patients presented with axillary lymphnodes metastasis and $82.9 \%$ were in stage II \& III. Duct cell carcinoma were in 41 cases (95.3\%). Tahara $\mathrm{H}$, Koyama $\mathrm{H}$ et $\mathrm{al}^{37}$, Aghadiuno $\mathrm{PU}^{38}$ claimed duct cell carcinoma is the commonest histological variety in male.

Whadimir $\mathrm{V}^{39}$ reported a case with pure squamous cell carcinoma in female breast, the incidence is exceedingly rare. In the present study, $87.5 \%$ of male breast cancers were duct cell carcinoma, only one case had squamous cell carcinoma. Like other studies, majority (62.5\%) were diagnosed in stage 111.

$75 \%$ cases had undergone simple mastectomy \& few with axillary dissection. Long term follow up could not be done. patients were followed up for variable period ranging from 6 month to 8 years.

\section{Conclusion:}

Primary male breast cancer accounts for 1-2\% of all neoplasia at this site (Norris \& Taylor 1969), Haaghensen, 1971, Friedman et al 1971, Friedman et al 1981). The average age of discovery is between 55-60 years of age, which is later that for the same tumor in females. Further more both long \& short term prognosis are less favorable in males (Treves \& Holleb 1955, Moss 1964 Robbin 1979).

It is evident that the prognosis of male breast cancer, like that of other cancers, is determined by multiple factors, no single known criterion can predict patient outcome accurately. From our limited data, simple mastectomy with axillary dissection, combined with other adjuvant modalities seems to offer the best chance of cure.
Many investigators (Butche 1961, Norris 1969, Haagenshen 1971, Robbins 1979) agree that the gravity of the prognosis of primary male breast cancer, even at short term, should be sought in anatomical structure of the male breast itself. When the supporting tissue is scares, even small neoplasia may gain access to the lymphatic \& haematogenous pathways and there after metastasize rapidly. We, therefore, maintain that the fundamental and indispensable prerequisites for a better prognosis are early diagnosis and timely \& appropriate therapy.

\section{Acknowledgement}

We remain indebted to director, Chittagong Medical College Hospital for his co operation regarding publication of this report.

\section{Reperences:}

1. Huang ZY, Qian H and Li J. Male breast cancer. Chinese Medical Journal. 1985; 98(1): 50-56.

2. Simmons RM. Male ductal carcinoma in situ presenting as bloody nipple discharge. A case report and literature review. Breast 2002; 8(2): 112 - 4.

3. Meguerditchian AN, Falardeau M, Martin G. Male breast carcinoma, Can J Surg 2002; 45(4): 296-302.

4. Hope-Stone HF. Radiotherapy in Clinical practice. 1st Edition; Butterwoth \& Co Ltd. 1984; P-90.

5. Somerville P. Carcinoma of the male breast. Report of 19 cases and review of the literature. Brit.J.Surg. 1951; 39:296303.

6. Treves $\mathrm{N}$ and Holleb AI. Cancer of the male breast. A report of 146 cases. Cancer 1955; 8:1239-50.

7. Moss HN. Cancer of the male breast. Annals NYAcad Sci. 1964; 114:937.

8. Sachs MD. Carcinoma of the male breast. Radiology. 1941; $37: 458$.

9. Payson BA and Rosh R. Carcinoma and other Neoplasms of the Male Breast Radiology. 1949; 52:220.

10. Holleb AI, Freeman HP and Farrow JH. Cancer of the Male breast Parts 1 and ll. NEJM 1968; 68:544-656.

11. Pack GT and Lefevre RG. Age and sex distribution and incidence of neoplastic disease at Memorial Hospital, New York City, J. cancer Res. 1930; 14:167.

12. Williams WR. Cancer of the male breast 100 cases. Lancet 1889; 2:261.

13. Wainwright J.M Carcinoma of the male breast. Arch. Surg (Chicago). 1927; 14:836- 859.

14. Huggins C, Jr and Taylor GW. Carcinoma of the male breast. Arch. Surg. 1955; 70:303. 
15. Bryan RC. Cancer of the breast in a boy of 15, Surg. Gyne. \& Obst. 1914;18:545.

16. Neal MP and Simpson BT. Diseases of the male breast. J. Missouri MA 1930; 27:565.

17. Charache H. Tumors of the male breast: Surgery. 1940; $7: 889$.

18. Gilbert JB. Carcinoma of the male breast. Surg Gynae Obs. 1933; 57:451.

19. Chase H. Treatment of Gynecomastia and cancer in the male breast in Pack GT and Ariel $1 \mathrm{M}$ (ed). Treatment of cancer and Allied Diseases, New York, Hoeber Medical Division, Harper \& Row Publishers. 1964; vol-4: P-231.

20. Abramson W, Warshawsky H. Cancer of the breast in the male secondary to estrogenic administration report of case. Urol. 1948; 59:76.

21. McClure JA and Higgins CC. Bilateral carcinoma of male breast after estrogen therapy. JAMA 1951; 146:7.

22. Neal PP. Malignant tumors of the male breast: Arch. Surg. 1933; 27:427.

23. Geschickter CF. Carcinoma and other diseases of the male breast in Diseases of the Breast. Philadelphia JB Lippincott Company. 1943; P-616.

24. Crichlow RW. Carcinoma of the Male Breast: Surg. Gyne. Obs. 1972; 134: 1011.

25. Crichlow RW. Breast cancer in males: Breast. 1976; 2:12.

26. Meyskens FL Jr. Tormey DC and Neiifeld JP. Male Breast Cancer. A review. Cancer Treatment Rev. 1976; 3:83.

27. Sandison AT.An autopsy study of the Adult Human breast. NCI Monograph \# 8, Washington DC. 1962; p78.

28. Scheike $\mathrm{O}$ and Visfeldt $\mathrm{J}$ Male Breast Cancer 4. Gynecomastia in patients with Breast Cancer. Acta Pathol Microbiol Scand. 1973;81:359.
29. Jackson AW, Muldal S, Ockey $\mathrm{CH}$ and O'connor PJ. Carcinoma of male breast in association with Klinefelter syndrome. BMJ.1965; 1: 223.

30. Sandison AT. Male breast cancer in Klinefelter's syndrome.ibid. 1965; I521.

31. Schottenfeld D, Nash AG, Robbins GF and Beattie. EJ Jr. Ten year Results of the Treatment of Primary Operble Breast carcinoma. A Summary of 304 patients evaluated by the TNM System. Cancer. 1976; 34: 1001.

32. Roswit B and Edlis H. Carcinoma of the male breast; A thirty years experience an literature review. Int.J. Radiat. Oncol. Biol. Phys. 1978; 4: 711-715.

33. Heller KS, Rosen PP, Schottenfeld D, Ashikari R and Kinne DW. Male breast cancer A clinicopathologic study of 97 cases. Ann. Surg. 1978; 188: 60-65,

34. Langlands AO. Maclean N. Ken GR. Carcinoma of the male breast report of a series of 88 cases. Clin. Radiol. 1976; 27: 21-25.

35. Donegan WL, Perez-Mesa C.Carcinoma of the male breast. Arch. Surg. 1973; 106:273-279.

36. $\mathrm{Xu} \mathrm{RN}$. Male breast cancer, clinical, pathologic and immunohistochemical study. Chung-Hua-Wai-Ko-TsaChih. 1989; 27(1): 28-30.

37. Tahara H. Koyama $\mathrm{H}$ et al. Carcinoma of male breast- with special reference to noninvasive carcinoma. Nippon-GenChiryo-Gakkai-Shi. 1989; 20: 24(3), 585 -91.

38. Aghadiuno PU. Cancer of the male breast: analysis of forty three cases in lbadan, Nigeria. Afr-J-Med-Med-Sci.1987; 16(1): $15-26$

39. Wladimir V Bogomoletz MD. Pure Squamous cell carcinoma of the breast. Arch Pathol Lab Med. 1982; Vol 106: P-57-59. 